\title{
Phytoplankton functional groups and harmful algal species in anthropogenically impacted waters of the NW Mediterranean Sea*
}

\author{
MAGDA VILA and MERCEDES MASÓ \\ Institut de Ciències del Mar (CSIC), Passeig Marítim de la Barceloneta, 37-49, 08003 Barcelona, Catalonia, Spain. \\ E-mail: magda@icm.csic.es
}

\begin{abstract}
SUMMARY: Phytoplankton assemblages were analysed by multivariate analysis techniques in highly modified waterbodies (harbours) of the northwestern Mediterranean Sea over an annual cycle. The phytoplankton functional groups that characterise these anthropogenically impacted waters were identified and related to HAB events. Four functional groups can be distinguished from the analysis: (1) bloom-forming dinoflagellates, (2) winter diatoms, (3) summer-autumn diatoms, and (4) large dinoflagellates and elongated diatoms. The species that characterise these functional groups occurred at all sampling stations. Potentially harmful species are distributed through all the clusters. However, bloom-forming dinoflagellates occur particularly in large harbours and during summer months. The results indicate that: (1) functional groups indicate where and when there is a high risk of blooms, but they cannot determine the risk of a toxic or fish-killing event; and (2) large harbours in tideless seas must be considered as areas with a high risk of high-biomass bloom occurrences.
\end{abstract}

Key words: phytoplankton assemblages, functional groups, toxic dinoflagellates, Mediterranean Sea, HAB.

RESUMEN: GRUPOS FUNCIONALES DE FITOPLÁNCTON Y ESPECIES TÓXICAS O NOCIVAS EN AGUAS DEL MEDITERRANEO NORDOCCIDENTAL IMPACTADAS ANTRÓPICAMENTE. - Se presentan los resultados de un analisis multivariante de asociaciones fitoplanctónicas en aguas confinadas (puertos) del Mediterráneo nordoccidental a lo largo de un ciclo anual. El objetivo del estudio es identificar los grupos funcionales de fitopláncton que caracterizan aguas impactadas por efectos antrópicos y determinar su relación con las incidencias de especies tóxicas o nocivas (HAB). Se han identificado cuatro grupos funcionales: (1) dinoflageados formadores de proliferaciones, (2) diatomeas de invierno, (3) diatomeas de verano-otoño, y (4) dinoflagelados y diatomeas de gran tamaño. En todas las estaciones muestreadas se detectan las especies que caracterizan los cuatro grupos funcionales. Sin embargo, los dinoflageados formadores de proliferaciones aparecen principalmente en puertos grandes y durante los meses de verano. Los resultados indican que: (1) Los grupos funcionales indican donde y cuando hay riesgo de proliferaciones, pero no pueden determinar el riesgo de un determinado evento tóxico. Y (2) los puertos grandes situados en mares con escasa amplitud mareal deben considerarse con un elevado riesgo de proliferaciones de elevada biomasa.

Palabras clave: asociaciones fitoplanctónicas, grupos funcionales, dinoflagelados tóxicos, mar Mediterráneo.

\section{INTRODUCTION}

Since the 1980s, an increase in Harmful Algal Bloom (HAB) events has been noted on a worldscale (Anderson 1989; Smayda 1990; Hallegraeff 1993), including Mediterranean waters (Honsell et

*Received January, 19, 2004. Accepted July 20, 2004. al., 1995; Vila et al., 2001a). Currently, HAB events are recognised as one of the main problems of coastal areas that affect the environment and coastal populations in many different ways. They lead to fauna death and the deterioration of water quality, and can have direct or indirect negative effects on human health (GEOHAB 2003). Anthropogenic influences such as nutrient over-enrichment of 
coastal waters, transport of harmful phytoplankton species via ballast-water vessels, and the translocation of shellfish stocks (Hallegraeff, 1998; Caroppo et al., 1999; Velikova et al., 1999; Moncheva et al., 2001) are considered to be the primary cause of the increase. The increase in man-made sheltered waters, as in harbours, jetties, etc. to provide protected embayments for vessels in tideless seas, has scarcely been considered in a similar manner (Vila et al., 2001a, c). In tourist destinations such as the Mediterranean coastline, there is a current trend towards an increase in sheltered water areas through construction of harbours, jetties and groins, and an increasing number of restricted-flow embayment areas. Although this type of shoreline development is global, there are major efforts in some Mediterranean areas that are now a major concern. For example, in Catalonia (NW Mediterranean coast) the number of harbours has increased from 12 in 1950 to 46 in 2003. These harbours are located along $575 \mathrm{~km}$ of coast, or approximately one harbour every $12.5 \mathrm{~km}$, or even less in some places. More harbours are being built, so the mean distance between harbours will decline in the future.

From the late 1980 s to the present, the number of $\mathrm{HAB}$ monitoring programmes has dramatically increased throughout the world (EUROHAB, 2002). However, most of them focus on just a few harmful species. This approach considerably reduces the predictability and understanding of the factors responsible for the blooms locally and fails to explain the current global increase in HABs (Estrada et al., 2003). Phytoplankton functional groups have been analysed in association with physical structures (Estrada et al., 1999; Pitcher et al., 2000; Roegner et al., 2002), and have been related to HAB species in upwelling systems (Fraga et al., 1988; Figueiras, 1994; Estrada, 1995). The relationship between anthropogenic activities and changes in phytoplankton composition and diversity is one of the main objectives proposed in HAB research (De Vries, 1998; Glibert et al., 2001; Anderson et al., 2002). Long time series on phytoplankton communities have recently been used to analyse HAB increase related to anthropogenic forcings (Solic et al., 1997; Beliaeff et al., 2001; Annevielle et al., 2002). However, the phytoplankton community approach has some handicaps: e.g. an important fraction of the species in natural samples cannot be identified and counted with routine methods, and also, one species name may hide a number of cryptic species (Zingone et al., 2003). Also, the availability of time series is scarce or inexistent in numerous regions where the anthropogenic pressure is highly significant. The purpose of the present paper is to analyse the spatial variability of the phytoplankton composition in an area where modification of the coastline's morphology is the most dramatic anthropogenic impact. The approach consists of examining phytoplankton functional groups by means of multivariate statistical techniques. The principal taxa of concern are potentially toxic species for humans (Paralytic shellfish poisoning (PSP), Diarrhetic shellfish poisoning (DSP), Amnesic shellfish poisoning (ASP) and Neurotoxic (NTX) producing species) as well as fish killers and other potentially bloom-forming dinoflagellates and diatoms. Functional groups are defined as non-phylogenetic associations of organisms that are based on physiological, morphological or other features that respond to recurrent patterns or factors similarly (Margalef, 1978; Gitay and Noble, 1997). This is the premise of the following text: the predictability of $\mathrm{HAB}$ is substantially increased when the focus is based on the identification of functional groups rather than on the identification of species.

\section{MATERIAL AND METHODS}

During 1996, phytoplankton species composition from nine different stations along the Catalan coast was analysed. Stations were selected to include: (1) anthropogenically impacted (harbour) areas, and (2) area coverage across the coast. These sites included eight harbours representing a range of sizes and a highly anthropogenically affected beach (near Barcelona City) (Fig. 1). Those harbours greater than 15 ha. were considered large whereas those less than 15 ha. were considered small. The harbours' properties and activities are presented in Table 1.

Weekly sampling was conducted from May to October and twice a month from November to April. Associated temperature and salinity were measured with a mercury thermometer and a microprocessor conductivity meter WTW Model LF197. Bucket phytoplankton samples $(150 \mathrm{ml})$ were taken at the surface from piers in each harbour. The non-confined station was sampled at the surface from the coast (near-shore waters, $0.5 \mathrm{~m}$ depth). Samples were preserved with formaldehyde (1\% final concentration). A $50 \mathrm{ml}$ aliquot was settled in a counting chamber for 1 day. For phytoplankton enumeration, the appropriate area of the chamber was 

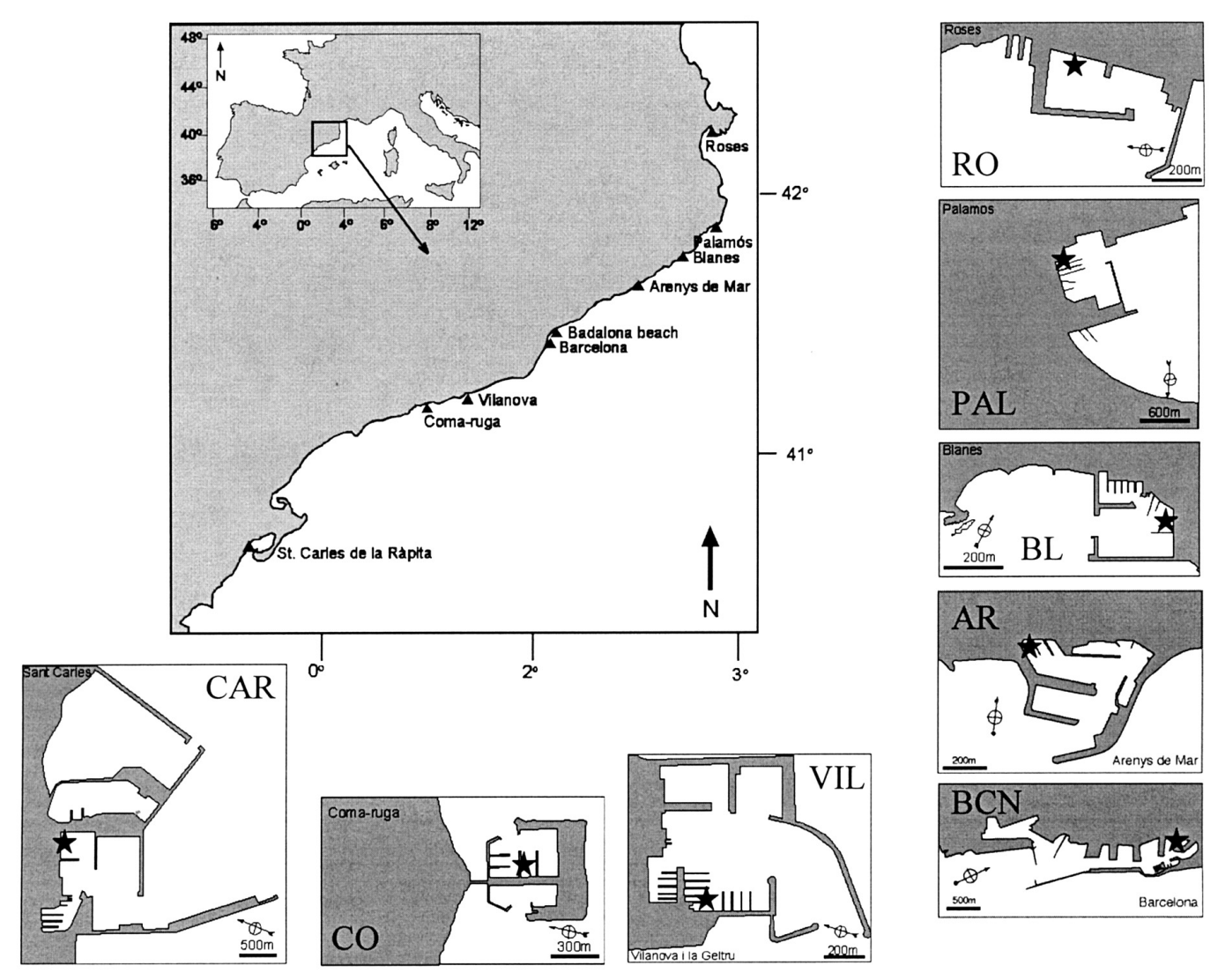

FIG. 1. - Study area showing the location of the nine stations. One beach (Badalona) and eight harbours are indicated as: RO: Roses; PAL: Palamós; BL: Blanes; AR: Arenys; BCN: Barcelona; VIL: Vilanova; CO: Coma-ruga; CAR: Sant Carles de la Ràpita.

scanned at $63-400 \mathrm{X}$ magnification using a LeicaLeitz DM-Il inverted microscope (Throndsen, 1995), depending on the abundance of each species. Usually at least three transects were scanned at $100 \mathrm{X}$, one transect at $400 \mathrm{X}$, and the complete chamber at $63 \mathrm{X}$. The minimum concentration that can be detected by this method is 20 cells $1^{-1}$. The entire phytoplankton community was identified to species or genus according to Tomas (1997), Daugbjerg et al. (2000), and the IOC list (2002); when identification was impossible, the different taxa were grouped into categories such as "small unidentified dinoflagellates" or "centric diatoms". Ciliates, tintinnids and rotifers were grouped as microzooplankton.

Similarities and differences within the phytoplankton community were analysed through the classical taxonomic approach (list of species, taxonomic ratios, abundance, diversity index, seasonal patterns) and also by means of Principal Component Analysis (PCA, STATISTICA for Windows, StatSoft, Tulsa). Margalef's and Pielou's evenness diversity index were calculated by means of

TABLE 1. - Sampling stations ordered from north to south, type of station (harbour or beach), type of each harbour (C-commercial, F-fishing, M-marina), and surface area. Harbours larger than 15 ha are considered large while those smaller than 15 ha are considered small.

\begin{tabular}{|c|c|c|c|c|c|c|c|}
\hline Station & Code & Lat. & Long. & Type of station & Type of harbour & Surface area (ha.) & Size \\
\hline Roses & RO & $42^{\circ} 15^{\prime} 0^{\prime \prime} \mathrm{N}$ & $3^{\circ} 10^{\prime} 0^{\prime \prime} \mathrm{E}$ & Harbour & FM & 12 & small \\
\hline Palamós & PAL & $41^{\circ} 50{ }^{\prime} 5^{\prime \prime} \mathrm{N}$ & $3^{\circ} 07^{\prime} 1^{\prime \prime} \mathrm{E}$ & Harbour & CFM & 5 & small \\
\hline Blanes & BL & $41^{\circ} 40^{\prime} 3^{\prime \prime} \mathrm{N}$ & $2^{\circ} 47^{\prime} 8^{\prime \prime} \mathrm{E}$ & Harbour & FM & 6 & small \\
\hline Arenys de Mar & AR & $41^{\circ} 34^{\prime} 3 " \mathrm{~N}$ & $2^{\circ} 33^{\prime} 3^{\prime \prime} \mathrm{E}$ & Harbour & FM & 17 & large \\
\hline Badalona & BAD & $41^{\circ} 26^{\prime} 5^{\prime \prime} \mathrm{N}$ & $2^{\circ} 15^{\prime} 7^{\prime \prime} \mathrm{E}$ & Beach & & & \\
\hline Barcelona & $\mathrm{BCN}$ & $41^{\circ} 26^{\prime} 4^{\prime \prime} \mathrm{N}$ & $2^{\circ} 10^{\prime} 2^{\prime \prime} \mathrm{E}$ & Harbour & CFM & 114 & large \\
\hline Vilanova & VIL & $41^{\circ} 12^{\prime} 3 " \mathrm{~N}$ & $1^{\circ} 43,7^{\prime \prime} \mathrm{E}$ & Harbour & CFM & 55 & large \\
\hline Coma-ruga & $\mathrm{CO}$ & $41^{\circ} 10^{\prime} 5^{\prime} \mathrm{N}$ & $1^{\circ} 30^{\prime} 8^{\prime \prime} \mathrm{E}$ & Harbour & M & 2 & small \\
\hline Sant Carles de la Ràpita* & CAR & $40^{\circ} 36^{\prime} 6^{\prime \prime} \mathrm{N}$ & $0^{\circ} 366^{\prime}{ }^{\prime \prime} \mathrm{E}$ & Harbour & CFM & 17 & large \\
\hline
\end{tabular}

* This harbour is situated in a bay 
TABLE 2. - Main characteristics of the taxa used in the multivariate analysis. The most common synonym of some species is indicated between brackets. The Code gives the key to the species names used in Figure 5. Taxonomic group (Tax Group) refers to dinoflagellates (DINO), diatoms (DIAT), coccolithophorids (COCO), flagellates (FL), silicoflagellates (SFL), and ciliates (CIL); Trophic State (auto-, hetero- or mixotrophic); Cell Type refers to individual cells (i), chain-forming or colonial cells (c); Harmful refers to the potentially harmful effect: Paralytic shellfish poisoning (PSP), Diarrhetic shellfish poisoning (DSP), Amnesic shellfish poisoning (ASP), Neurotoxic (NTX), fish-killing and bloom-forming (bf; cell concentrations over $10^{6}$ cells $1^{-1}$; an asterisk (bf*) indicates known bloom-forming species but blooms were not observed in 1996). Habitat Type refers to the dinoflagellate habitat classification proposed by Smayda and Reynolds (2001). Np: number of occurrences in one year (total $=327$ samples); $\% \mathrm{~Np}$ : percentage of total; Av. $>0$ : averaged concentration $\left(\right.$ cells $1^{-1}$ ), calculated from frequency which cells were detected; Max.: Maximum cell concentration (cells $1^{-1}$ ).

\begin{tabular}{|c|c|c|c|c|c|c|c|c|c|c|}
\hline Taxa & Code & $\begin{array}{c}\text { Tax } \\
\text { Group }\end{array}$ & $\begin{array}{l}\text { Trophic } \\
\text { State }\end{array}$ & Cell Type & Harmful & $\begin{array}{l}\text { Habitat } \\
\text { Type }\end{array}$ & $\mathrm{Np}$ & $\% \mathrm{~Np}$ & Av. $(>0)$ & $\operatorname{Max}$ \\
\hline Alexandrium minutum & AMIN & DINO & auto & $\mathrm{i}$ & $\mathrm{PSP}, \mathrm{bf}$ & I & 77 & 24 & 32238 & $2.0 \mathrm{E}+06$ \\
\hline Ceratium furca & CFUR & DINO & $\operatorname{mixo}$ & $\mathrm{i}$ & & VI-VIII & 92 & 28 & 69 & 400 \\
\hline Ceratium fusus & CFUS & DINO & mixo & $\mathrm{i}$ & Fish-killing & III & 66 & 20 & 58 & 360 \\
\hline Dinophysis rotundata & DROT & DINO & mixo & $\mathrm{i}$ & DSP & VII & 30 & 9 & 149 & 1500 \\
\hline Dinophysis sacculus & DSAC & DINO & mixo & $\mathrm{i}$ & DSP & VII & 103 & 31 & 852 & 40950 \\
\hline \multicolumn{11}{|l|}{ Akashiwo sanguinea } \\
\hline (=Gymnodinium splendens) & GSPL & DINO & auto/mixo & $\mathrm{i}$ & bf* & & 55 & 17 & 111 & 910 \\
\hline Gyrodinium cf. spirale & GYRO & DINO & hetero & $\mathrm{i}$ & & & 143 & 44 & 1371 & 116935 \\
\hline \multicolumn{11}{|l|}{ Gymnodinium impudicum } \\
\hline (=Gyrodinium impudicum) & GIMP & DINO & auto & $\mathrm{c}$ & bf* & & 48 & 15 & 33207 & 388143 \\
\hline Heterocapsa sp. & HETE & DINO & auto & $\mathrm{i}$ & bf* & II & 117 & 36 & 9349 & 481770 \\
\hline Prorocentrum micans & PMIC & DINO & auto & $\mathrm{i}$ & bf* & II & 203 & 62 & 2949 & 76440 \\
\hline Prorocentrum minimum & PMIN & DINO & auto & $\mathrm{i}$ & NTX, bf* & II & 86 & 26 & 4074 & 165620 \\
\hline Prorocentrum triestinum & PTRI & DINO & auto & $\mathrm{i}$ & bf & II & 185 & 57 & 65504 & $4.0 \mathrm{E}+06$ \\
\hline Protoperidinium diabolum & PDIA & DINO & hetero & $\mathrm{i}$ & & & 70 & 21 & 95 & 910 \\
\hline Protoperidinium spp. small & PRTP & DINO & hetero & $\mathrm{i}$ & & & 164 & 50 & 984 & 15453 \\
\hline Scrippsiella spp. & SCRI & DINO & auto & $\mathrm{i}$ & bf & II & 196 & 60 & 31335 & $1.7 \mathrm{E}+06$ \\
\hline Asterionellopsis glacialis & AGLA & DIAT & auto & $\mathrm{c}$ & bf* & & 74 & 23 & 14217 & 177905 \\
\hline Cerataulina pelagica & CPEL & DIAT & auto & $\mathrm{c}$ & bf & & 111 & 34 & 31482 & $1.8 \mathrm{E}+06$ \\
\hline Coscinodiscus spp. & COSC & DIAT & auto & $\mathrm{i}$ & & & 58 & 18 & 53 & 455 \\
\hline centric diatom sp. 1 & CEN & DIAT & auto & $\mathrm{i}$ & bf & & 107 & 33 & 24722 & $1.0 \mathrm{E}+06$ \\
\hline \multicolumn{11}{|l|}{ Chaetoceros curvisetus+ } \\
\hline pseudocurvisetus & $\mathrm{CHCP}$ & DIAT & auto & $\mathrm{c}$ & & & 70 & 21 & 8879 & 85540 \\
\hline Chaetoceros lorenzianus & CHLO & DIAT & auto & $\mathrm{c}$ & & & 59 & 18 & 1831 & 10010 \\
\hline Chaetoceros spp. large $(>20 \mu \mathrm{m})$ & $\mathrm{CHG}$ & DIAT & auto & $\mathrm{c}$ & & & 72 & 22 & 6412 & 94640 \\
\hline Chaetoceros spp. small & CHP & DIAT & auto & $\mathrm{c}$ & bf & & 132 & 40 & 70424 & $2.7 \mathrm{E}+06$ \\
\hline Dytilum brightwellii & DBRI & DIAT & auto & $\mathrm{i}$ & & & 45 & 14 & 1012 & 13195 \\
\hline Eucampia zodiacus & EZOD & DIAT & auto & $\mathrm{c}$ & & & 31 & 9 & 3030 & 17745 \\
\hline Lauderia sp. & LAUD & DIAT & auto & $\mathrm{c}$ & & & 48 & 15 & 4868 & 41405 \\
\hline \multicolumn{11}{|l|}{ Leptocylindrus danicus } \\
\hline$(+$ minimus $)$ & LDAN & DIAT & auto & $\mathrm{c}$ & bf & & 180 & 55 & 26916 & $1.8 \mathrm{E}+06$ \\
\hline \multicolumn{11}{|l|}{ Cylindrotheca closterium+ } \\
\hline Nitzschia longissima & NCL & DIAT & auto & $\mathrm{i}$ & bf & & 260 & 80 & 10483 & 487301 \\
\hline Odontella spp. (Biddulphia) & ODON & DIAT & auto & $\mathrm{c}$ & & & 98 & 30 & 646 & 22295 \\
\hline Pleurosigma spp. & PLEU & DIAT & auto & $\mathrm{i}$ & & & 206 & 63 & 132 & 9100 \\
\hline Proboscia alata & PALA & DIAT & auto & $\mathrm{c}$ & & & 54 & 17 & 313 & 2275 \\
\hline Pseudo-nitzschia spp. & PSEU & DIAT & auto & $\mathrm{c}$ & ASP, bf & & 198 & 61 & 29889 & $1.5 \mathrm{E}+06$ \\
\hline Rhizosolenia cf. imbricata & RIMB & DIAT & auto & $\mathrm{c}$ & & & 76 & 23 & 3312 & 44590 \\
\hline \multicolumn{11}{|l|}{ Dactyliosolen fragilissimus } \\
\hline (=Rhizosolenia fragilissima) & RFRA & DIAT & auto & $\mathrm{c}$ & & & 45 & 14 & 4642 & 61812 \\
\hline \multicolumn{11}{|l|}{ Guinardia striata } \\
\hline (=Rhizosolenia stolterfothii) & RSTO & DIAT & auto & $\mathrm{c}$ & & & 41 & 13 & 548 & 2727 \\
\hline Skeletonema costatum & $\mathrm{SKCO}$ & DIAT & auto & $\mathrm{c}$ & bf & & 107 & 33 & 111373 & $5.0 \mathrm{E}+06$ \\
\hline Thalassionema nitzschioides & THNI & DIAT & auto & $\mathrm{c}$ & bf* & & 159 & 49 & 5902 & 230230 \\
\hline Thalassiosira spp. & THAL & DIAT & auto & $\mathrm{c}$ & bf* & & 94 & 29 & 21932 & 447372 \\
\hline Syracosphaera pulchra & SYRP & $\mathrm{COCO}$ & auto & $\mathrm{i}$ & & & 29 & 9 & 973 & 4550 \\
\hline Eutreptiella gymnastica & EUTR & FL & auto & $\mathrm{i}$ & bf* & & 175 & 54 & 12853 & 325611 \\
\hline Dictyocha fibula & DFIB & SFL & auto & $\mathrm{i}$ & Fish- killing & & 52 & 16 & 558 & 1365 \\
\hline Mesodinium cf. rubrum & MESO & $\mathrm{CIL}$ & $\operatorname{mixo}$ & $\mathrm{i}$ & bf* & & 126 & 39 & 6300 & 299061 \\
\hline
\end{tabular}

PRIMER 5 for Windows (Plymouth Routines In Multivariate Ecological Research). PCA was based on the correlation matrix of all data collected over an annual cycle at all nine stations (327 samples) and 42 species as descriptors (from a total of 171 taxa identified) (Table 2). Cell densities were logarithmically transformed prior to analysis. Those taxa which had been lumped into the broadest categories as well as those that only occasionally appeared in samples $(<9 \%)$ were excluded.

In order to interpret the PCA derived axes, correlation coefficients were calculated between the values of the factor scores of the samples for the first three axes and relevant parameters such as taxonomic groups, diversity index, or other factors that could affect phytoplankton distribution. A K-means 

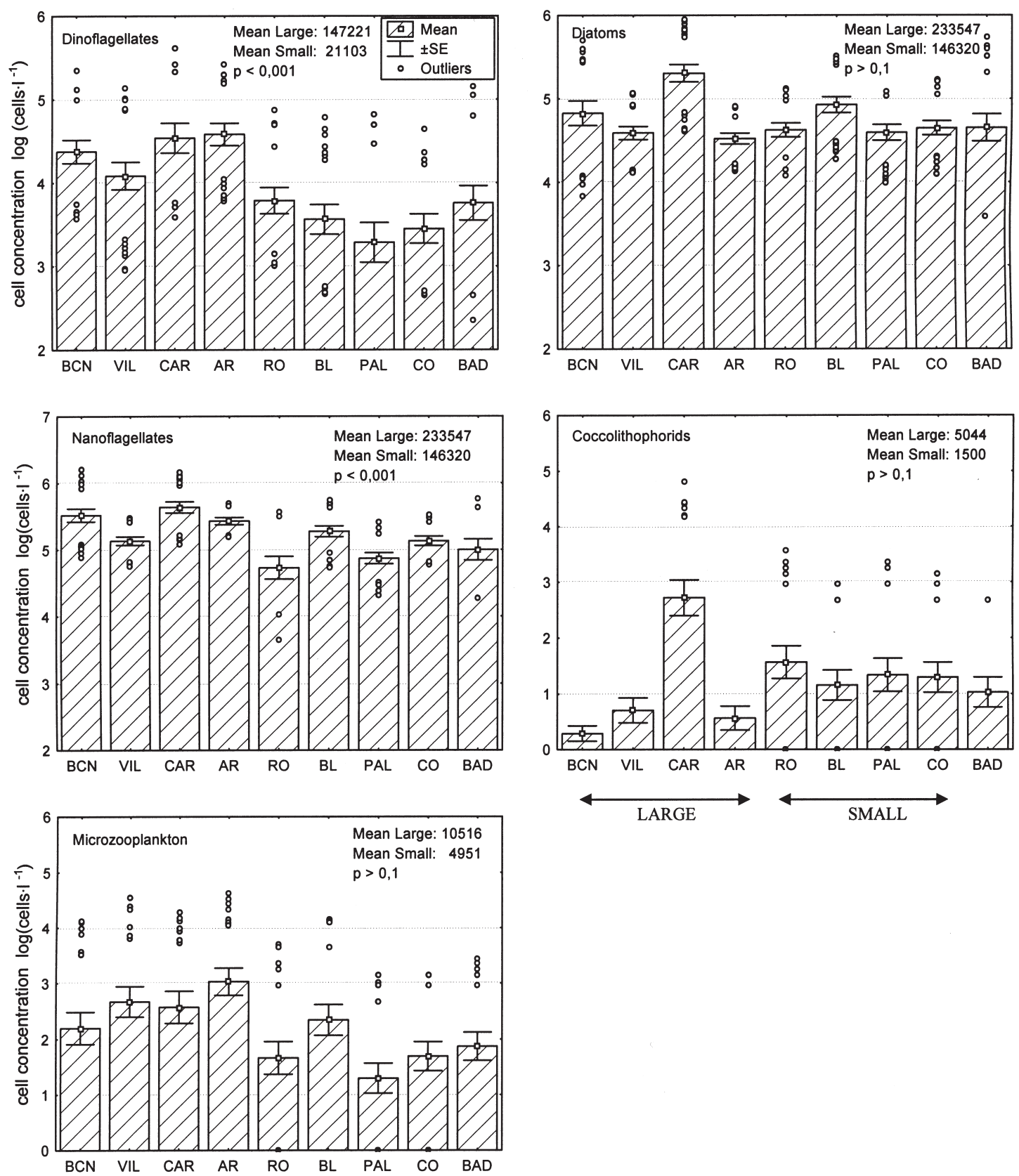

FIG. 2. - Annual average concentrations $( \pm$ SE) of dinoflagellates, diatoms, nanoflagellates, coccolithophorids and microzooplankton at each of the stations from north to south (station codes as in Table 1). The results of the t-student analysis comparing cell concentrations in large harbours vs. small ones are indicated.

clustering (Euclidean distances) was applied to the PCA factor loadings (3 first axes) to identify groups of species objectively $(\mathrm{k}=4)$.

\section{RESULTS}

\section{Spatio-temporal distribution}

General patterns are shown in annual concentrations of dinoflagellates, diatoms, coccolithophorids, nanoflagellates and microzooplankton for each of the stations studied (Fig. 2). The average annual concentration of dinoflagellates and nanoflagellates was significantly higher in large harbours than in small ones (t-student, $\mathrm{p}<0.001)$. The microzooplankton showed the same tendency although it was not significant. The average annual concentration of diatoms was high everywhere $\left(10^{4}-10^{5}\right.$ cells $\left.1^{-1}\right)$, with no significant differences between the stations. The concentration of coccolithophorids was low compared to that of the other groups, and the maxi- 
mum concentrations were detected in the sourthernmost harbour (St. Carles).

The seasonal variability of dinoflagellates and diatoms is shown in Figure 3, where five selected harbours are arranged from north to south. In general, maximum dinoflagellate concentrations were detected during spring and summer. However, some latitudinal gradient is apparent. Maximum concentrations were noted in the southernmost harbours (St. Carles, Coma-ruga and Vilanova) in spring-early summer, whereas in the northern harbours (Blanes and Roses), maximum concentrations were noted in summer. Dinoflagellate concentrations were relatively low during winter $\left(10^{3}-10^{4}\right.$ cells $\left.\mathrm{l}^{-1}\right)$ and did not reach higher concentrations than $10^{5}$ cells $1^{-1}$, except for St. Carles where Gyrodinium corsicum reached 43000 cells $1^{-1}$ in January. There was no clear seasonal pattern for diatoms. However, if the relative abundance of both groups is examined, dinoflagellates predominated during the warm months, whereas the relative concentrations of diatoms were highest during the rest of the year (Fig. 4).

In the 327 samples counted, 171 taxa were identified. The most common and abundant species among the thecate dinoflagellates were Scrippsiella spp., Prorocentrum triestinum, $P$. minimum, $P$. micans, small Protoperidinium spp. and Heterocap$s a$ sp. Other species such as Ceratium furca, and $C$. fusus were frequently recorded but cell concentra-

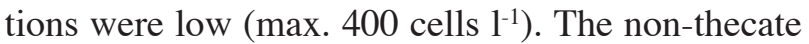
Gyrodinium cf. spirale was recorded year-round and attained the highest cell concentrations (max. 105 cells $1^{-1}$ ) during the summer. Alexandrium minutum (PSP-producer) was also observed year-round but its highest concentrations $\left(>10^{5}\right.$ cells $\left.1^{-1}\right)$ occurred in winter and spring. Dinophysis sacculus (DSP-producer) and Gymnodinium impudicum (=Gyrodinium impudicum) bloomed in spring and summer. Alexandrium catenella (PSP-producer) was detected for the first time in the study area in 1996, particularly in the Barcelona harbour during the summer months. Prorocentrum rhathymum and Pratjetella medusoides were frequently detected during autumn. The later is a rarely reported species which exceptionally was abundant along the Catalan coast in 1996 (pers. obs.). Gyrodinium corsicum (fish-killing species) was only recorded at one harbour in the southern area (St. Carles harbour) and reached its highest concentrations during the winter-spring months.

The most commonly recorded and abundant diatoms were Asterionellopsis glacialis, Chaeto-
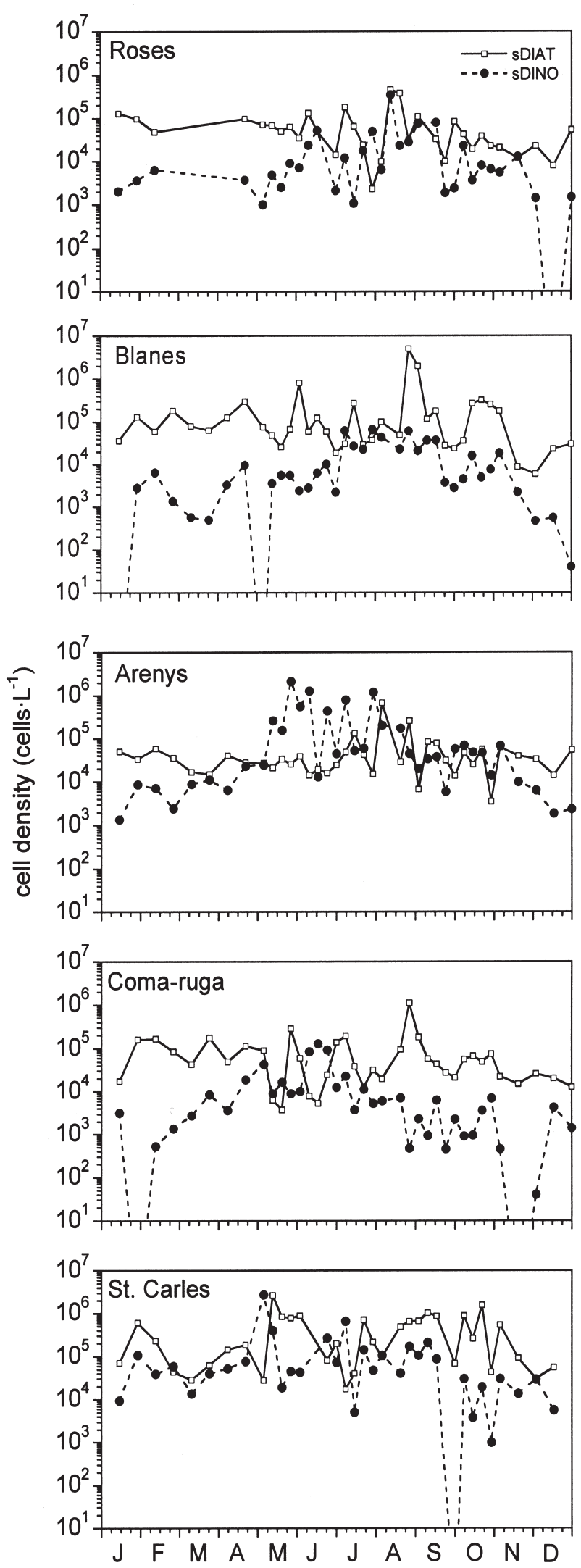

FIG. 3. - Total dinoflagellate and diatom cell densities at five selected stations in 1996 (sampled weekly from May to October and twice a month during the rest of the year). 

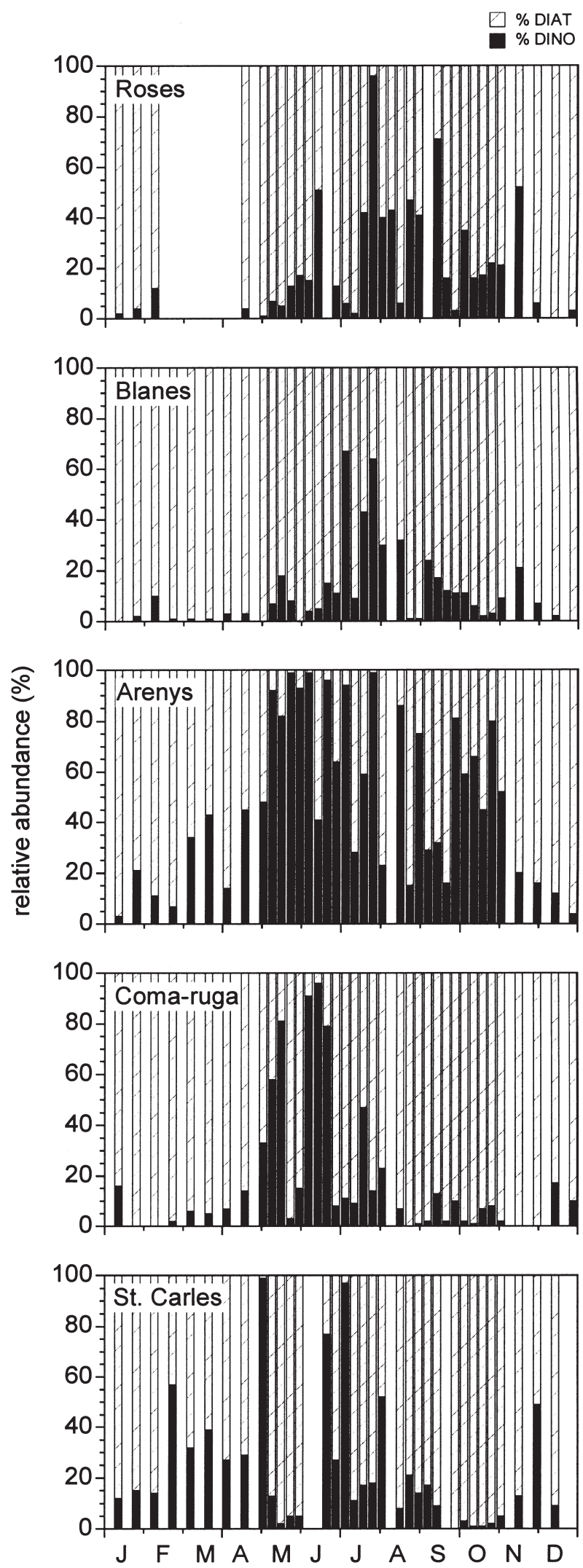

FIG. 4. - Relative abundance of dinoflagellates (black) and diatoms (striped) at five selected stations. The phytoplankton relative abundance is examined here as if it was only composed by these two groups. (White bars are the weeks which were not sampled). ceros spp., Cylindrotheca closterium (+ Nitzschia longissima), Leptocylindrus danicus (+ minimus), Pseudo-nitzschia spp. and Thalassionema nitzschioides. Ditylum brightwellii and Eucampia zodiacus were recorded during the winter and Skeletonema costatum bloomed during the summer and autumn.

Few coccolithophorids were recorded except in the St. Carles harbour. Within this group, Acanthoica quattrospina, Calciosolenia murrayi, Rabdosphaera claviger, and Syracosphaera pulchra were identified. The silicoflagellates Dictyocha fibula and D. speculum were also present all along the coast although concentrations were low $(<1500$ cells $1^{-1}$ ). As for nanoflagellates, cells similar to the Cryptomonas, Pyramimonas, Chrysohcromulina, and Calycomonas genera were also recorded throughout the region. The flagellate Eutreptiella gymnastica and the ciliate Mesodinium cf. rubrum were also common and abundant in the plankton.

\section{HAB species}

Twenty-seven identified taxa could potentially lead to harmful effects (e.g. toxic, fish-killing, or bloom-forming); data on their relative contribution (HAB index) are presented in Table 3. Among them, 11 species are potentially toxic to humans. The occurrence of potentially toxic dinoflagellates (IOC list 2002) such as Alexandrium minutum, Dinophysis sacculus, and Prorocentrum minimum was quite high, and present in the 24,31 , and $26 \%$ of samples respectively. Some taxa were bloom-forming species that characterise surface water discoloration, e.g. A. minutum reaching concentrations as high as $10^{6}$ cells $1^{-1}$ in the Arenys Harbour in the spring of 1996. As the dominant species, it contributed up to $96 \%$ of the microphytoplankton community. Prorocentrum rhathymum never reached high concentra-

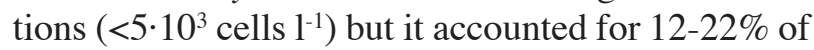
the microphytoplankton community in autumn in Blanes and Palamós harbours. Since Steidinger (1983) P. rhathymum has been assumed to be synonymous of Prorocentrum mexicanum. However, it has been separated into two different species recently (Cortés-Altamirano and Sierra-Beltran, 2003). Although the chemical toxin structure of $P$. mexicanum is undefined, it is known that it does not produce okadaic acid or dinophysistoxin. However, many toxic effects have been observed. Although there are no direct evidences, when both species were considered synonymous, $P$. mexicanum was 
TABLE 3. - List of potentially harmful species (HAB) observed on the Catalan coast during 1996. It includes potentially toxic species for humans (with syndromes indicated), potentially fish-killing species, and potentially bloom-forming dinoflagellates and diatoms. The taxonomic group (Tax Group) is indicated: dinoflagellates (DINO), diatoms (DIAT), and silicoflagellates (SFL). \% Np: percentage of the number of occurrence ( $\geq 9$ species included in the PCA analysis). Max.: maximum abundances (cells $\left.1^{-1}\right)$. HAB index: percentage of the harmful species with respect to the total microphytoplankton community (dinoflagellates plus diatoms plus silicoflagellates). The HAB index of the two major events (Highest concentrations reached by the harmful species during the annual cycle) are shown.

\begin{tabular}{|c|c|c|c|c|}
\hline Species & Tax Group & $\% \mathrm{~Np}$ & Max Cells $1^{-1}$ & HAB index \\
\hline \multicolumn{5}{|l|}{ Human potentially toxic species ${ }^{1}$} \\
\hline \multicolumn{5}{|l|}{ Paralytic Shellfish Poisoning (PSP) } \\
\hline Alexandrium minutum* & DINO & 24 & 2026332 & $63-96$ \\
\hline Alexandrium catenella* & DINO & 3 & 36400 & $<10$ \\
\hline \multicolumn{5}{|l|}{ Diarrhetic Shellfish Poisoning (DSP) } \\
\hline Dinophysis acuta & DINO & 1 & 20 & $<1$ \\
\hline Dinophysis caudata & DINO & 6 & 460 & $<1$ \\
\hline Dinophysis rotundata & DINO & 9 & 1500 & $<5$ \\
\hline Dinophysis sacculus & DINO & 31 & 40950 & $<5$ \\
\hline Dinophysis tripos & DINO & 0.3 & 20 & $<1$ \\
\hline Prorocentrum lima & DINO & 2 & 240 & $<1$ \\
\hline Prorocentrum rhathymum** & DINO & 7 & 4368 & $12-22$ \\
\hline \multicolumn{5}{|l|}{ Amnesic Shellfish Poisoning (ASP) } \\
\hline \multirow{2}{*}{\multicolumn{5}{|c|}{ Neurotoxic (NTX, mouse assay) ${ }^{2}$}} \\
\hline & & & & \\
\hline Prorocentrum minimum* & DINO & 26 & 165620 & $20-45$ \\
\hline \multicolumn{5}{|l|}{ Potentially fish-killing species ${ }^{3}$} \\
\hline Ceratium fusus* & DINO & 20 & 360 & $<1$ \\
\hline Gyrodinium corsicum* & DINO & 4 & 43225 & $10-17$ \\
\hline Noctiluca scintillans* & DINO & 1 & 20 & $<1$ \\
\hline Dictyocha fibula* & SFL & 16 & 1365 & $<1$ \\
\hline Dictyocha speculum* & SFL & 2 & 910 & $<5$ \\
\hline \multicolumn{5}{|l|}{ Potentially bloom-forming species ${ }^{4}$} \\
\hline Akashiwo sanguinea $(=$ Gymnodinium splendens) & DINO & 17 & 910 & $<1$ \\
\hline Cerataulina pelagica & DIAT & 34 & 1841840 & $72-92$ \\
\hline Centric diatom sp. 1 & DIAT & 33 & 1026324 & $63-79$ \\
\hline Gymnodinium (=Gyrodinium) impudicum & DINO & 15 & 388143 & $48-69$ \\
\hline Heterocapsa sp. & DINO & 36 & 481770 & $33-59$ \\
\hline Leptocylindrus danicus & DIAT & 55 & 1796067 & $65-92$ \\
\hline Prorocentrum micans & DINO & 62 & 76440 & $6-12$ \\
\hline Prorocentrum triestinum & DINO & 57 & 4000000 & $81-96$ \\
\hline Scrippsiella spp. & DINO & 60 & 1671066 & $71-77$ \\
\hline Skeletonema costatum & DIAT & 33 & 5000040 & $90-97$ \\
\hline Small Chaetoceros spp. & DIAT & 40 & 2671074 & $82-93$ \\
\hline
\end{tabular}

${ }^{1}$ Known species that are potentially toxic: PSP, DSP, ASP, NTX (IOC list 2002).

${ }^{2}$ Responsible for mouse mortality via a water-soluble toxin. However, there are no data indicating impacts to human consumers (Grzebyk et al., 1997)

3 Those species that are known or suspected to cause fish losses in mariculture (Anderson et al., 2001).

${ }^{4}$ Those species that are known to produce blooms elsewhere (Anderson et al., 2001) or that occasionally reached abundances exceeding $10^{6}$ cells $1^{-1}$ in our samples.

* Species that are potentially toxic or fish-killing and also known to reach cell concentrations of $10^{6}$ cells $1^{-1}$. In this study, blooms $>10^{6}$ cells

$1^{-1}$ were only detected in Alexandrium minutum and Pseudo-nitzschia.

** It is not a true DSP-producing species as it does not produce okadaic or dinophysistoxin, but it has been related to diarrhetic symptoms (Levasseur et al., 2003).

related to diarrhetic symptoms (Levasseur et al., 2003 and references therein).

The genus Dinophysis was usually present in low concentrations $\left(<1.5 \cdot 10^{3}\right.$ cells $\left.1^{-1}\right)$ and with a low HAB index $(<5 \%)$, except for occasional peaks in $D$. sacculus where cell concentrations of up to $4 \cdot 10^{4}$ cells $1^{-1}$ were noted. However, the HAB index for $D$. sacculus remained low even at this time, as it generally coincided with A. minutum blooms of several million cells per litre.

The genus Pseudo-nitzschia spp. (known to contain several toxic species) was present in $61 \%$ of the analysed samples. Three potentially toxic species have been identified from this region, $P$. pungens, $P$. delicatissima, and $P$. pseudodelicatissima (Vila 2001). In 1996, the main Pseudo-nitzschia spp. blooms occurred during May, July, September and October.

Harmful phytoplankton species that are known or suspected to cause fish mortalities in mariculture (Anderson et al., 2001) have also been detected in the study area, generally with a low HAB index $(<5 \%)$, except for G. corsicum, which reached 10$17 \%$ of the microphytoplankton community. 
Species known to produce generally harmless water discolorations (Anderson et al., 2001) or those that surpassed $10^{6}$ cells $\mathrm{l}^{-1}$ in our samples were considered potentially bloom-forming. Bloom-forming dinoflagellates were present in $87 \%$ of the samples. Considering the definition of this group, almost all of these taxa (e.g. Gymnodinium impudicum, Prorocentrum triestinum, Scrippsiella spp.) have a high HAB index ( $>60 \%)$, as was true with bloom-forming diatoms such as Cerataulina pelagica, Leptocylindrus danicus and Skeletonema costatum. There were some exceptions, such as $A$. sanguinea and $P$. micans, described as potentially bloom-forming in other areas but not in our area of study, where they showed consistent low HAB indexes.

\section{Phytoplankton functional groups}

The PCA was undertaken by using a matrix made with the samples as objects (327 samples) and species as variables (42 taxa). Codes and main features of the species included in the PCA are presented on Table 2. Five potentially toxic species, two suspected fishkilling taxa, and all of the potentially bloom-forming species were included in the analysis. The other detected harmful species were not included in the PCA analysis because they occurred in less than 9\% of the samples (Table 3). In order to define the main phytoplankton assemblages objectively, a K-means cluster analysis $(\mathrm{k}=4)$ was applied to the factor coordinates of the species of the three first axes.

The three main axes of the multivariate analysis (PCA) account for $28.9 \%$ of the variance ( $1=13.5 \%$; $\mathrm{f} 2=8.8 \%$; $\mathrm{f}=6.5 \%$ ). Factor 1 shows the highest positive correlation with total dinoflagellates (Table 4). Factor 1 also has a high and significant positive correlation with temperature, total nanoflagellates, and microzooplankton. Factor 2 showed a strong negative correlation with the two diversity index (TOTAL SP, MARGALEF) and biomass (TOTAL IND). Its correlation is also negative with all of the analysed groups, but particularly diatoms. Factor 3 had a significant negative correlation with temperature and total diatoms, and a significant positive correlation with the Margalef index. The correlation between harbour size and the three factors ( 1 positive, 2 and 3 negative) should be noted (Table 4).

Figure 5a give the factors' loadings of the variables (species) in the space defined by factors 1-2. Negative values of the first axis are associated with some diatoms which are present most often during cold months (Ditylum brightwellii, Eucampia zodia-
TABLE 4. - Correlation between the first three factors of the principal components analysis and other related variables: surface area of the harbour (SIZE), water temperature (TEMP), salinity (SAL), number of species (TOTAL SP), number of individuals (TOTAL IND), Margalef's index (MARGALEF), Pielou's evenness index (PIELOU), sum of coccolithophorids (sCOCO), diatoms (sDIAT), dinoflagellates (sDINO), nanoflagellates, (sNANO), and microzooplankton (sMICROZOO). Correlations with * are significant at $\mathrm{p}<$ 0.05 , those with $* *$ are significant at $\mathrm{p}<0.01$. N ranged between 290 and 327.

\begin{tabular}{|c|c|c|c|c|c|c|}
\hline & $\mathrm{F} 1$ & & $\mathrm{~F} 2$ & & F3 & \\
\hline SIZE & 0.14 & $*$ & -0.18 & $* *$ & -0.31 & $* *$ \\
\hline TEMP & 0.61 & $* *$ & 0.09 & & -0.25 & $* *$ \\
\hline SAL & -0.10 & & 0.08 & & 0.02 & \\
\hline TOTAL SP & 0.15 & $* *$ & -0.92 & $* *$ & 0.09 & \\
\hline TOTAL IND & 0.23 & $* *$ & -0.95 & $* *$ & -0.02 & \\
\hline MARGALEF & 0.11 & $*$ & -0.87 & $* *$ & 0.13 & $*$ \\
\hline PIELOU & -0.02 & & -0.33 & $* *$ & -0.07 & \\
\hline $\mathrm{sCOCO}$ & 0.08 & & -0.11 & & 0.00 & \\
\hline sDIAT & -0.01 & & -0.56 & $* *$ & -0.14 & $*$ \\
\hline sDINO & 0.71 & $* *$ & -0.33 & $* *$ & 0.06 & \\
\hline SNANO & 0.35 & $* *$ & -0.30 & $* *$ & -0.05 & \\
\hline sMICROZOO & 0.30 & $* *$ & -0.43 & $* *$ & -0.04 & \\
\hline
\end{tabular}

cus, Rhizosolenia cf. imbricata, Odontella sp.) and positive values with most dinoflagellates (Alexandrium minutum, Dinophysis sacculus, Akashiwo sanguinea, Gyrodinium cf. spirale, Gymnodinium impudicum). The second axis separates rich samples (high abundance and diversity) from poor samples. The most negative values were associated with diatoms such as Thalassionema nitzschioides, Centric diatom sp. 1, Pseudo-nitzschia spp., Chaetoceros spp., Cerataulina pelagica, and Leptocylindrus danicus (+ minimus).

In Figure 5b, the species are presented in the space defined by factors $1-3$, jointly with the results of the K-means cluster analysis (4 groups). Factor 3 discriminates better between diatoms detected in winter and those detected in summer-autumn, and it also discriminates these species from the spring ones. Cluster 1 basically contains dinoflagellates that can reach very high concentrations, the bloomforming dinoflagellates. Diatoms typical of winter are found in cluster 2, while those that bloom in summer and autumn are found in cluster 3 . The groups were designated winter diatoms and summerautumn diatoms respectively. Finally, cluster 4 contains, among others, a mixture of large dinoflagellates and elongated diatoms.

In Figure 6, scatterplots of the values of the coordinates of the objects (samples) of Barcelona and Palamós, as representative of large and small harbours, are presented in the space defined by factor 1 and 2. Small harbours were typified most frequently by positive values of factor 2 whilst showing very few 

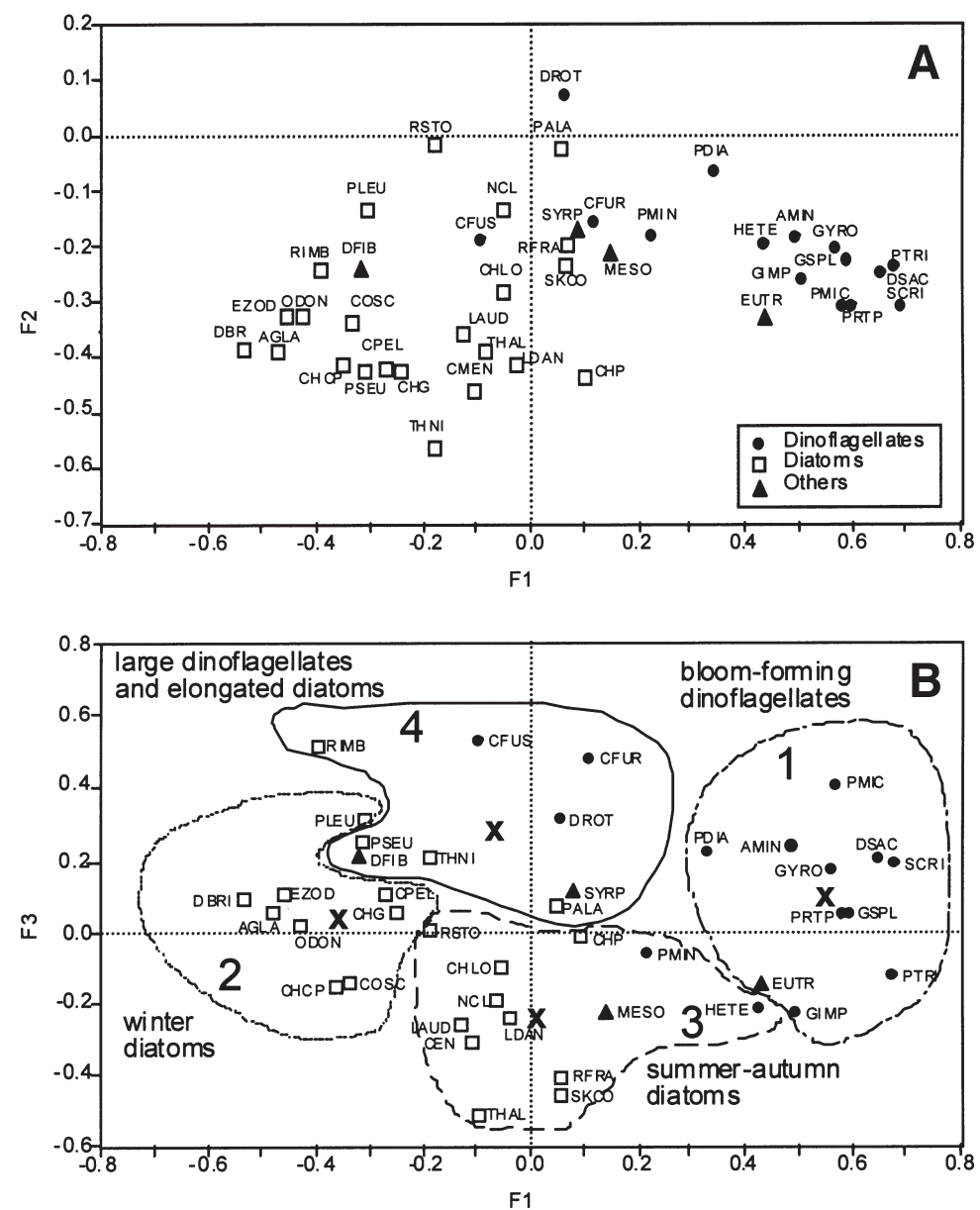

FIG. 5. - Scatterplot of the factor loadings of the variables (species) in the space determined: a) by the first and second principal components and b) by the first and third principal components. The results of a K-means clustering (Euclidean distances) were applied to the factor scores of the three first axes to objectively identify functional groups. The cluster center coordinates are indicated (X). The functional groups identified are bloom-forming dinoflagellates (cluster 1), winter diatoms (cluster 2), summer-autumn diatoms (cluster 3), and large dinoflagellates and elongated diatoms (cluster 4). Identification codes for species are found in Table 2.
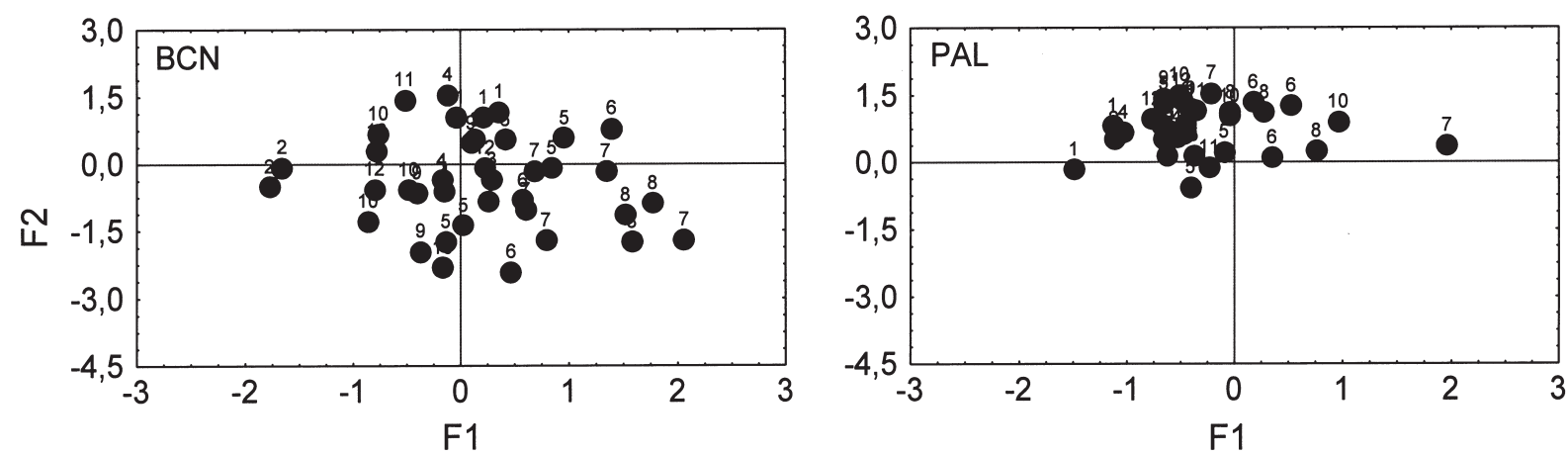

FIG. 6. - Scatterplot of factor score coefficients of the objects (samples) in the space defined by factors 1 and 2 in a large (Barcelona-BCN) and a small (Palamos -PAL) harbour (numbers indicates months). In general, the largest harbours are characterised by high values of factor 1 and low values of factor 2 .

cases of high positive values of factor 1 . On the other hand, large harbours (> 15 ha.) were represented by high positive values of factor 1 . In relation to factor 2 , large harbours had samples scattered along the axis, quite different to those noted for the small harbours.
The space defined by factors 1 and 3 clearly shows phytoplankton seasonal succession. The seasons of the year can be observed in a clockwise direction (Fig. 7a). It is clear from Figure 7b that this seasonal pattern is displaced in relation to the har- 

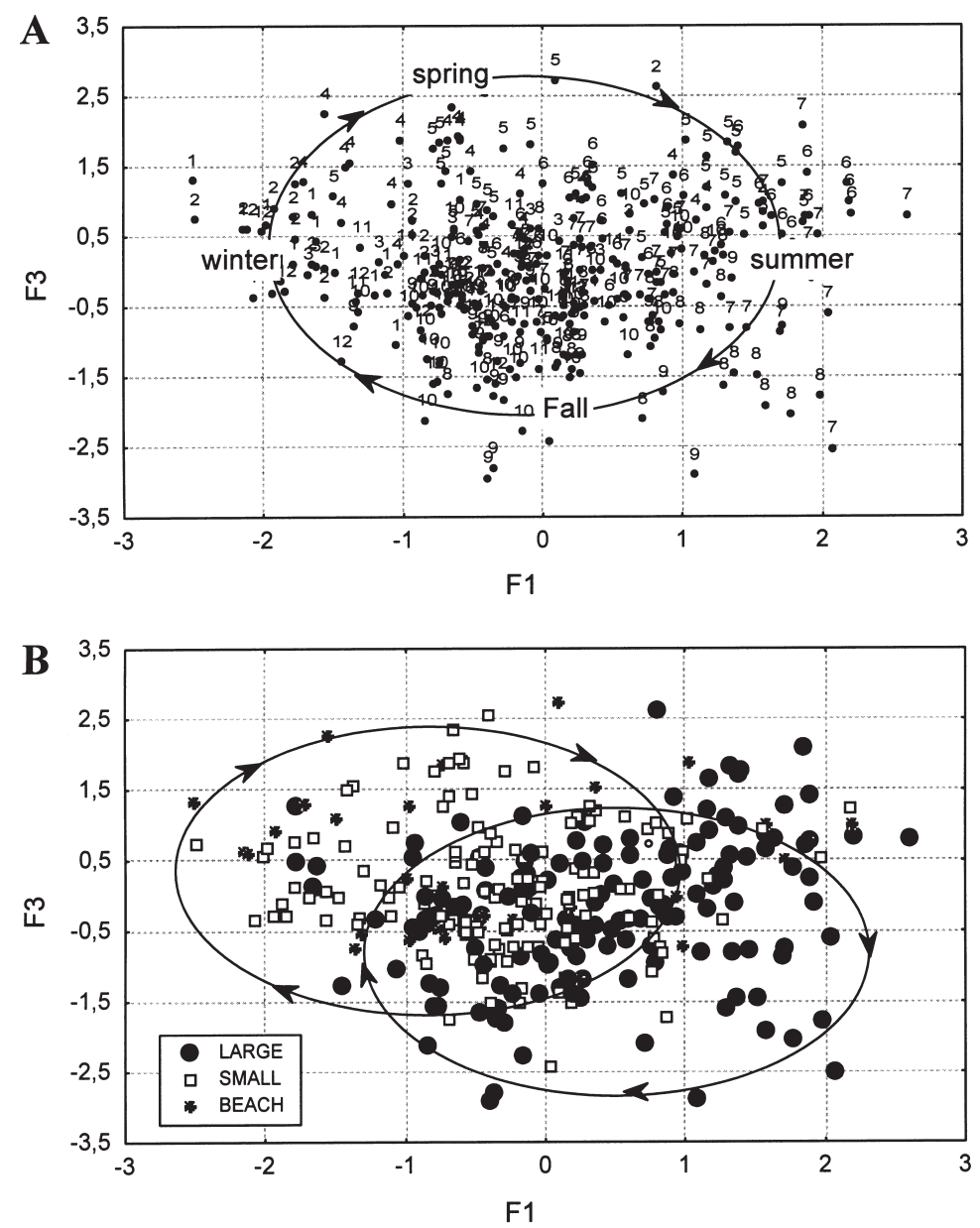

FIG. 7. - Scatterplot of factor score coefficients of the objects (samples) in the space defined by factors 1 and 3: a) Sampling month is noted and seasons are presented clockwise; b) Harbour size. The largest surface-area harbours tend to be dominated by dinoflagellates (right side), while diatoms dominate the smallest surface-area harbours (left side). The seasonal sucession in the phytoplankton community is displaced to the right in large and to the left in small harbours.

bour size. Cluster 1 (bloom-forming dinoflagellates) is related to summer (specially in June-July) and principally large harbours. The small harbours are mostly related to cluster 2 and 4 (winter diatoms and large dinoflagellates and elongated diatoms).

\section{DISCUSSION}

The general trends in annual phytoplankton succession found in the present study coincided with those that have been previously described, as well as with recent studies for the region (e.g. López and Arté, 1972; Estrada, 1980; Mura et al., 1996; Cebrián and Valiela, 1999).

In general, all species detected in this study were distributed along the entire coast, with only two exceptions, Gyrodinium corsicum and Alexandrium catenella. The former was only detected in St. Car- les harbour, as previously reported (Garcés et al., 1999; Vila et al., 2001a). At the same harbour the maximum cell concentrations of coccolithophorids were also found. The fact that Gyrodinium corsicum is only found in this harbour and that coccolithophorids are found in their highest concentrations there is probably related to the fact that St. Carles is the only harbour which is situated in a bay.

A. catenella is possibly a new introduced species in the Mediterranean Sea. After it had been detected for the first time in Barcelona harbour in 1996, it colonised the nearby harbours, increasing its geographical distribution (Vila et al., 2001c; Lilly et al., 2002). Apart from these exceptions, no latitudinal spatial pattern was found with regard to species composition.

In general, large dinoflagellates are characteristic of the summer (stratification and low nutrient availability), and diatoms are associated with winter and 
TABLE 5. - Concentrations of chlorophyll $\left(\mu \mathrm{g} \cdot \mathrm{L}^{-1}\right)$ and major inorganic nutrients $(\mu \mathrm{M})$. Data were derived from an extensive environmental monitoring programme for 2 annual cycles in the near-shore Catalan surface waters. Even though the sampling period for the nutrient data does not coincide (1998-2000) with the period of the present study, the data presented were collected at the stations sampled in the present study $(\mathrm{n}=250)$. Frequency of single nutrient limitation (\% of observations) was calculated as in Justic et al. (1995) (criteria detailed below).
P limitation $\left(\mathrm{Lim} \mathrm{PO}_{4}\right)$ :
N limitation (Lim DIN):
$\mathrm{P}<0.1 \mu \mathrm{M}$
$\mathrm{DIN}<1 \mu \mathrm{M}$
DIN:P > 22; Si:P > 22
Si limitation (Lim Si):
$\mathrm{Si}<2 \mu \mathrm{M}$
DIN:P $<10 ;$ Si:DIN $>1$
$\mathrm{Si}: \mathrm{P}<10 ; \mathrm{Si}: \mathrm{DIN}<1$

\begin{tabular}{|c|c|c|c|c|c|c|c|c|}
\hline & Chl-a Median & $\mathrm{PO}_{4}$ Median & $\mathrm{SiO}_{4}$ Median & DIN Median & $\operatorname{Lim} \mathrm{PO}_{4}$ & Lim DIN & $\operatorname{Lim} \mathrm{Si}$ & $\mathrm{n}$ \\
\hline Open & 1.30 & 0.35 & 3.56 & 13.41 & 0 & 0 & 1 & 50 \\
\hline Small & 0.87 & 0.39 & 2.15 & 4.55 & 0 & 2 & 2 & 83 \\
\hline Large & 2.64 & 0.60 & 3.56 & 9.64 & 0 & 1 & 2 & 117 \\
\hline All Grups & 1.38 & 0.42 & 3.02 & 7.90 & 0 & 3 & 5 & 250 \\
\hline
\end{tabular}

spring, a period with no stratification and relatively high nutrient content (Margalef, 1978). However, in contrast to open Mediterranean waters known to be nutrient-depleted during the summer months, nearcoastal waters are rich in nutrients year-round, even in summer (Olivos et al., 2002). Moreover, phytoplankton production rarely appears to be potentially limited by nutrient defficiency in confined waters along the Catalan coast (Table 5). During the summer months, most dinoflagellate blooms appear as a clear property of these near-coastal enriched waters and $\mathrm{HAB}$ species are also very frequent and abundant (Table 3 and Fig. 5b).

\section{Functional groups and HAB species}

The classical definition of Margalef's Mandala (Margalef, 1978; Margalef et al., 1979) is an attempt to define functional groups in marine waters. The Mandala, which describes marine phytoplankton succession, maps the distribution of different phytoplankton species in an ecological space defined by turbulence and nutrient levels. R-selected species (basically diatoms) are followed by $\mathrm{k}$-selected species (large dinoflagellates) in the main sequence of species succession. In this conceptual model, there is a coincidence between primary phylogenetic groups and functional groups. According to Margalef, red tides would only occur if high nutrient concentrations co-occurred with relatively low turbulence. The species growing under these conditions would out-compete their neighbors through adaptations such as vertical migration, grazer deterrence, and allelopathic inhibition of potential competitors (Cullen et al., 2002 and references therein).

The groups that characterise the anthropogenic impacted waters of the Catalan coast in our analysis were: bloom-forming dinoflagellates (cluster 1), winter diatoms (cluster 2), summer-autumn diatoms (cluster 3), and large dinoflagellates and elongated diatoms (cluster 4) (Fig. 5b). Cluster 1, the bloomforming dinoflagellates, is typified by small, more or less rounded, autotrophic, neritic species with many cyst-formers (e.g. A. minutum, G. impudicum, P. triestinum, Scripsiella spp.) or r-strategists. Cluster 1 also contained heterotrophic dinoflagellates which are suspected to prey on these small species (Gyrodinium sp., P. diabolum). Cluster 4 was typified by large mixotrophic dinoflagellates (Ceratium spp.) with their horns/morphology yielding a high surface to volume ratio; elongated diatoms were also distinct to this group. Both have relatively low growth rates (Garcés and Masó 2001) and can be considered K-strategists. The remainder of the diatoms fall into two different groups according to the season. Thus, we distinguish summer-autumn diatoms (cluster 3) and winter diatoms (cluster 2).

Smayda and Reynolds (2001) have focused exclusively on dinoflagellates. They distinguished a range of nine different habitats or environmental situations associated with different dinoflagellate lifeforms. A combination of two distinct gradients (onshore-offshore and mixing-nutrient) is used in this classification. Although diatom blooms are generally associated with high turbulence and high nutrient concentrations (Margalef, 1978), our results indicate that they could also be situated across a similar gradient to that proposed by Smayda and Reynolds (2001) for the dinoflagellates. Summerautumn diatoms (e.g. Skeletonema costatum, Leptocylindrus danicus and small Chaetoceros spp.) is a group of bloom-forming diatoms differentiated by the multivariate analysis that, in fact, coexists with the bloom-forming dinoflagellates although in lower concentrations (Fig. 5b).

The coexistence between bloom-forming dinoflagellates and summer-autumn diatoms implies a common response to the same environmental conditions. 
A

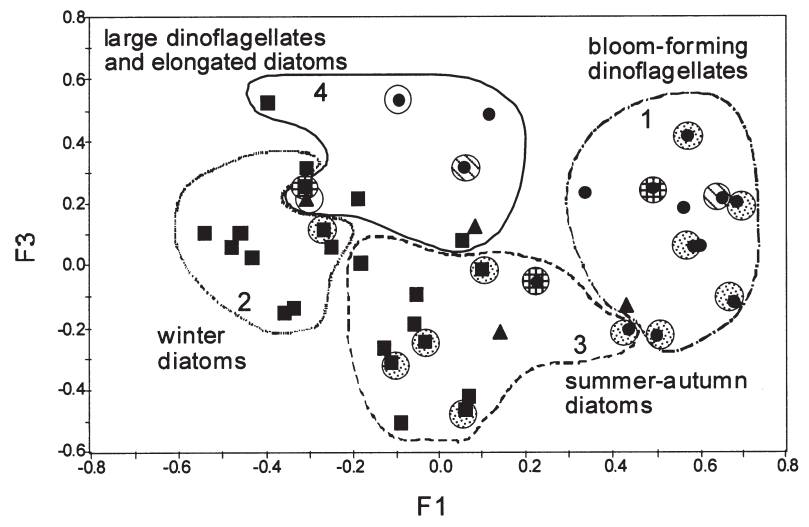

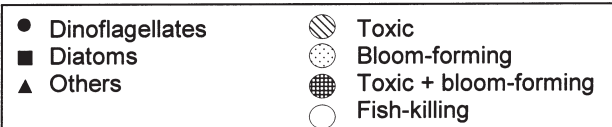

$+\quad$ Turbulence

B

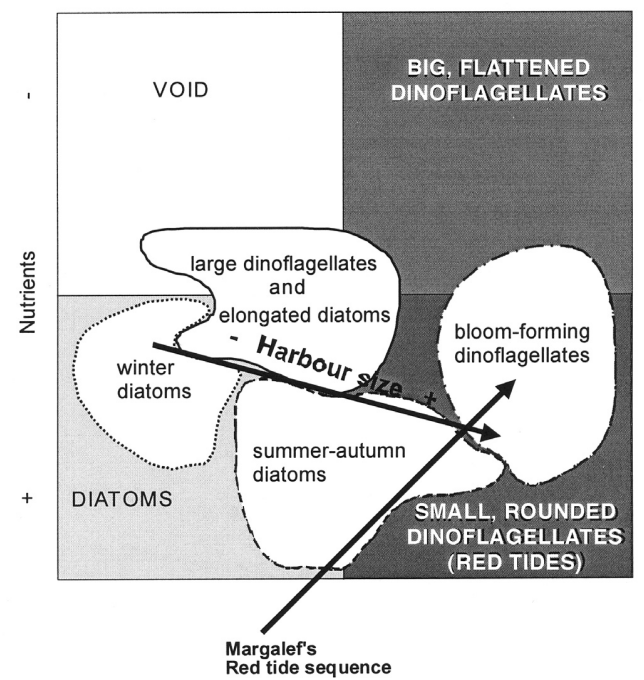

FIG. 8. - A) Functional groups identified by the cluster analysis (Fig. 5b), in which the potentially harmful species have been pointed out according to their potential harm (toxic, bloom-forming, fish-killing and toxic plus bloom-forming) (Table 3). B) Schematic representation of the functional groups incorporated in Margalef's Mandala, rotated $180^{\circ}$. Only the two nutrient-rich quadrants of the Mandala are represented by our study habitats, and harbour size defines the diagonal of these quadrants.

In Figure 8a, the different harmful species have been pointed out according to their potential harm (toxic, bloom-forming, fish-killing, and toxic plus bloomforming) (Table 3). Most bloom-forming species are grouped in two clusters, basically cluster 1 for dinoflagellates and cluster 3 for diatoms. On the other hand, the toxic species are scattered across all the functional groups. Thus, the most probable species associations are predictable in the analyses employed in this study. However, there is little probability of predicting a toxic event across the spectrum of conditions considered in this assessment.

\section{The importance of the harbour size}

The functional groups defined in this study have been overlapped on Margalef's Mandala (rotated $180^{\circ}$, Fig. 8b). Only the two nutrient-rich quadrants of Margalef's theory include our study habitats. Margalef's quadrant of flattened dinoflagellates is not well represented in the habitats sampled in the present study, as the habitats along the coast are characterised by high nutrient concentrations and a wide range of turbulence related to seasonality.

From results along the Catalan coast, there appears to be a relationship between the harbour size and the frequency of and cell concentration in dinoflagellate blooms (cluster 1). The main difference found between large and small harbours is that dinoflagellate abundances are higher in the largest harbours than in the smallest embayments (Fig. 2). The same assemblages are detected at all stations but the bloom-forming dinoflagellate group is less represented in small harbours. Additionally, this group is also less represented in winter than in summer (Fig. $7 b)$. Harbour size, therefore, seems to be critically important to the occurrence and recurrence of dinoflagellate blooms in the region. The probable explanation for this relationship is through the hydrodynamics of a harbour with perhaps larger harbours characterised by deeper basins, longer distances from the mouth to headwaters, and potentially longer water residence times relative to smaller harbours in the area. Although large harbours seem to be characterised by higher nutrient levels than small ones, there is no indication of differences concerning the frequency of potential nutrient limitation (Table 5). Therefore, the interaction between high nutrient levels and confinement plays the key role in the occurrence of dinoflagellate blooms in this region.

The largest harbours are also typified by high commercial shipping traffic, important vectors in translocating cysts of harmful phytoplanktonic species (Hallegraeff, 1998; Hamer et al., 2001; Marangoni et al., 2001). After a dormancy period, these cysts germinate to yield vegetative populations and potential bloom precursors. The cysts, ballast transported and locally produced cells experience recurrent germination over 10-20 years (Hallegraeff, 1998), potentially reseeding blooms for decades. Confined waters areas (e.g. harbours) have recently been shown to be reservoirs of large beds of resting cysts (Garcés et al., 2004).

After species settlement and colonisation in a harbour, the species has a new array of suitable habi- 
tats to colonise, forming a basis for establishment in near neighbours. In fact, coastal currents in the study area approximate $10-20 \mathrm{~cm} \cdot \mathrm{s}^{-1}$ (Masó and Tintoré, 1991), favouring advection of cells to adjacent harbours in 1 day. The expansion of A. catenella on the Catalan coast (Vila et al., 2001b, c) is probably a result of this process. During the widespread bloom of A. catenella in 1998 and 1999, huge patches of cells were noted inside the harbours $\left(>10^{6}\right.$ cells $\left.1^{-1}\right)$, with far lower concentrations in open near-coastal areas $\left(<10^{4}\right.$ cells $\left.1^{-1}\right)$. The series of small harbours along the coast therefore play a key role in cell dissemination coastwide via the very short distances between sheltered waters.

These characteristics indicate that large harbours in tideless seas should be considered as areas with a high probability of high-biomass blooms. They are rich in nutrients and, as cell dispersion is limited, actively growing cells would accumulate in the harbour. This model of dinoflagellate blooms in semiclosed or closed bays, estuaries or harbours is not new and, in fact, is widely known in some areas. For example, inshore-offshore differences in phytoplankton biomass were found in the Ria de A Coruña (NW Spain); cell concentrations were much higher in the harbour area (inner part of the Ria), where residence was long and could be considered an accumulation area (Varela et al., 2001). Estuaries and coastal waters with high flushing rates have significantly less algal production than similar systems that are poorly flushed, consistent with the general pattern that shallow systems typically support more algal growth than deeper systems (Anderson et al., 2002 and references therein).

The increase of man-sheltered structures associated with harbour construction may be important in cell dissemination along the coast, particularly with the limited distances between sheltered areas of the region. Therefore, proliferation of blooms in the area might be expected as shore development proceeds in this highly valued coastal system.

\section{ACKNOWLEDGEMENTS}

The authors are indebted to Kevin Sellner, who kindly reviewed and improved the latest version of the manuscript. We thank Marta Estrada and Esther Garcés for useful criticisms, and Jordi Camp for his support in our work. This study was partly supported by the Agència Catalana de l'Aigua (Department de Medi Ambient, Generalitat de Catalunya) and
CSIC through the contract "Plà de vigilància de fitoplàncton nociu i tòxic a la Costa Catalana", and by the European Community project STRATEGY (EVK3-CT-2001-00046). Field work was supported by the Direcció General de Pesca Marítima (Generalitat de Catalunya).

\section{REFERENCES}

Anderson, D.M. - 1989. Toxic algal blooms and red tides: A global prespective. In: T. Okaichi, D.M. Anderson and T. Nemoto (eds.), Red tides: biology, environmental science and toxicology, pp. 11-16. Elsevier, New York.

Anderson, D.M., P. Andersen, V.M. Bricelj, J.J. Cullen and J.E. Rensel. - 2001. Monitoring and management strategies for Harmful Algal Blooms in coastal waters. Asia Pacific Economic Program, Singapore, and Intergovernmental Oceanographic Commission, Paris.

Anderson, D.M., P.M. Glibert and J.M. Burkholder. - 2002. Harmful algal blooms and eutrophication: Nutrient sources, composition, and consequences. Estuaries, 25: 704-726.

Anneville, O., V. Ginot, J.C. Druart and N. Angeli. - 2002. Longterm study (1974-1998) of seasonal changes in the phytoplankton in Lake Geneva: a multi-table approach. J. Plankton Res., 24, 993-1008.

Beliaeff, B., P. Gros, C. Belin, B. Raffin, I. Gailhard and J.-P. Durbec. - 2001. 'Phytoplankton events' in French coastal waters during 1987-1997. Oceanol. Acta., 24, 425-433.

Caroppo, C., A. Fiocca, P. Sammarco and G. Magazzu. - 1999. Seasonal Variations of Nutrients and Phytoplankton in the Coastal SW Adriatic Sea (1995-1997). Bot. Mar., 42: 389-400.

Cebrián J. and I. Valiela. - 1999. Seasonal patterns in phytoplankton biomass in coastal ecosystems. J. Plankton Res., 21: 429-444.

Cortés-Altamirano, R. and A.P. Sierra-Beltrán. - 2003. Morphology and taxonomy of Prorocentrum mexicanum and reinstatement of Prorocentrum rhathymum (Dinophyceae). J. Phycol., 39: $221-225$

Cullen, J.J., P.J.S. Franks, D.M. Karl and A. Longhurst. - 2002. Physical influences on marine ecosystem dynamics. In: A. R. Robinson, J. J. McCarthy and B. J. Rothschild (eds.), The Sea, pp. 297-336. John Wiley and Sons, New York.

Daugbjerg N., G. Hansen, J. Larsen and O. Moestrup. - 2000. Phylogeny of some of the major genera of dinoflagellates based on ultrastructure and partial LSU rDNA sequence data, including the erection of three new genera of unarmoured dinoflagellates. Phycologia, 39(4): 302-317.

De Vries, I., R.N.M. Duin, J.C.H. Peeters, F.J. Los, M. Bokhorst and R.W.P.M. Laane. - 1998. Patterns and trends in nutrient and phytoplankton in Dutch coastal waters: comparison of time-series analysis, ecological model simulation, and mesocosm experiments. ICES J. Mar. Sci., 55: 620-634.

Figueiras, F.G. - 1994. Red tide assemblage formation in an estuarine upwelling ecosystem: Ria de Vigo. J. Plankton Res., 16: 857-878.

Fraga, S., D.M.Anderson, I. Bravo, B. Reguera, K.A. Steidinger and C.M.Yentsch. - 1988. Influence of upwelling relaxation on dinoflagellates and shellfish toxicity in Ria de Vigo, Spain. Estuar. Coast. Shelf Sci., 27: 349-361.

Estrada M. - 1980. Composición taxonómica del fitopláncton en una zona próxima a la desenvocadura del río Besós (Barcelona), de octubre de 1978 a marzo de 1979. Inv. Pesq., 44(2): 275-289.

Estrada, M. - 1995. Dinoflagellate assemblages in the Iberian upwelling area. In: P. Lassus, G. Arzul, E. Erard, P. Gentien and C. Marcaillou (eds.), Harmful marine algal blooms, pp. 157-162. Lavoiser Publishing, Paris.

Estrada, M., R.A. Varela, L. Salat, A. Cruzado and E. Arias. - 1999. Spatio-temporal variability of the winter phytoplankton distribution across the Catalan and North Balearic fronts (NW Mediterranean). J. Plankton Res., 21, 1-20.

Estrada, M., E. Berdalet, M. Vila, and C. Marrasé. - 2003. Effects of pulsed nutrient enrichment on enclosed phytoplankton: ecophysiological and successional responses. Aquat. Microb. Ecol., 32: 61-71. 
EUROHAB. - 2002. European Initiative on Harmful Algal Blooms In: E. Granéli and E. Lipiatou (eds.), Research and infrastructural needs. National European and International programmes, p. 141. Belgium: European Commission Directorate General for Research.

Garcés, E., I. Bravo, M. Vila, R.I. Figueroa, M. Masó and N. Sampedro. - 2004. Relationship between vegetative cells and cyst production during Alexandrium minutum bloom in Arenys de Mar harbour (NW Mediterranean). J. Plankton Res., 26; 637-645.

Garcés, E., M. Delgado, M. Masó and J. Camp. - 1999. In situ growth rate and distribution of the ichthyotoxic dinoflagellate Gyrodinium corsicum Paulmier in an estuarine embayment (Alfacs Bay, NW Mediterranean Sea). J. Plankton Res., 21: 1977-1991.

Garcés, E. and M. Masó. - 2001. Phytoplankton potential growth versus increase in cell numbers: estimation of cell lysis. Mar. Ecol. Prog. Ser., 212: 297-300.

GEOHAB. - 2003. Global Ecology and Oceanography of Harmful Algal Blooms, Implementation Plan. P. Gentien, G. Pitcher, A. Cembella, P. Glibert (eds.). SCOR and IOC, Baltimore and Paris. 44 pp.

Gitay, H. and I.R. Noble. - 1997. What are functional types and how should we seek them? In: T. M. Smith, H. H. Shugart and F. I. Woodward (eds.), Plant Functional Types. Their relevance to ecosystem properties and global change, pp. 3-19. Cambridge University Press, Cambridge.

Glibert, P.M., R. Magnien, M.W. Lomas, J. Alexander, C.K. Fan, E. Haramoto, M. Trice and T.M. Kana. - 2001. Harmful algal blooms in the Chesapeake and coastal bays of Maryland, USA Comparison of 1997, 1998, and 1999 events. Estuaries, 24 875-883.

Grzebyk, D., A. Denardou, B. Berland and Y.F. Pouchus. - 1997. Evidence of a new toxin in the red-tide dinoflagellate Prorocentrum minimum. J. Plankton Res., 19: 1111-1124.

Hallegraeff, GM. - 1993. A review of harmful algal blooms and their apparent global increase. Phycologia, 32: 79-99.

Hallegraeff, GM. - 1998. Transport of toxic dinoflagellates via ship's ballast water: bioeconomic risk assessment and efficacy of possible ballast water management strategies. Mar. Ecol. Prog. Ser., 168, 297-309.

Hamer, J.P., I.A.N. Lucas and T.A. McCollin. - 2001. Harmful dinoflagellate resting cysts in ships' ballast tank sediments: potential for introduction into English and Welsh waters. Phy cologia, 40: 246-255.

Honsell, G., P. Nichetto, L. Sidari and A. Tubaro. - 1995. Toxic dinoflagellates in the Mediterranean Sea. G. Bot. Ital., 129, 391-403.

IOC list. - 2002. IOC Taxonomic Reference List of Toxic Algae. Intergovernmental Oceanographic Commission of UNESCO.

Justic, D., N. Rabalais, R. Turner and Q. Dortch. - 1995. Changes in nutrient structure of river-dominated coastal waters: Stoichimetric nutrient balance and its consequences. Estuar. Coast. Shelf Sci., 40: 339-356.

Levasseur, M., J.Y. Couture, A.M. Weise, S. Michaud, M. Elbrachter, G. Sauve and E. Bonneau. - 2003. Pelagic and epiphytic summer distributions of Prorocentrum lima and P. mex icanum at two mussel farms in the Gulf of St. Lawrence, Canada. Aquat. Microb. Ecol., 30:283-293.

Lilly, E.L., D.M. Kulis, P. Gentien and D.M. Anderson. - 2002 Paralytic shellfish poisoning toxins in France linked to a human-introduced strain of Alexandrium catenella from the western Pacific: evidence from DNA and toxin análisis. $J$. Plankton Res., 24: 443-452.

López, J. and P. Arté. - 1972. Aguas rojas en el Mediterraneo Occidental. Publ. Técnicas Dirección General de Pesca Marítima, 10: $399-412$

Marangoni, C., R.N. Pienaar and S.D. Sym. - 2001. Possible introduction of alien phytoplankton via shipping ballast water: A South African perspective. S. Afr. J. Bot., 67: 465-474.

Margalef, R. - 1978. Life-forms of phytoplankton as survival alternatives in an unstable environment. Oceanol. Acta, 1(4): 493-509.

Margalef R, M. Estrada and D. Blasco. - 1979. Functional morphology of organisms involved in red tides, as adapted to decaying tur- bulence. In: D.L. Taylor and H.H. Seliger (eds.) Toxic dinoflagellate blooms, pp. 89-94. Elsevier, North Holland.

Masó, M. and J. Tintoré. - 1991. Variability of the shelf water off NE Spanish coast. J. Mar. Syst., 1: 441-450.

Moncheva, S., O. Gotsis-Skretas, K. Pagou and A. Krastev. - 2001. Phytoplankton Blooms in Black Sea and Mediterranean Coastal Ecosystems Subjected to Anthropogenic Eutrophication: Similarities and Differences. Estuar. Coast. Shelf Sci., 53: 281-295.

Mura, M., S. Agustí, J. Cebrián and M. Satta. - 1996. Seasonal variability of phytoplankton biomass and community production in Blanes Bay (March 1992-March 1994). In: C. Duarte (ed.), Seasonality in Blanes Bay: a paradigm of the northwest Mediterranean littoral, pp. 23-30. Publ. Espec. Inst. Esp. Oceanogr., Madrid.

Olivos, A., M. Masó and J. Camp. - 2002. Continental runoff of nutrients and their possible influence over stoichiometric ratios (DIN:P:Si) in the northweastern Mediterranean waters of Spain (Catalan Sea). Cienc. Mar., 28(4): 393-406.

Pitcher, G.C. and D. Calder. - 2000. Harmful algal blooms of the southern Benguela Current: A review and appraisal of monitoring from 1989 to 1997. S. Afr. J. Mar. Sci., 22: 255-271.

Roegner, G., B.M. Hickey, J.A. Newton, A.L. Shanks and D. Armstrong. - 2002. Wind-induced plume and bloom intrusions into Willapa Bay, Washington. Limnol. Oceanogr., 47: 1033-1042.

Smayda, T.J. - 1990. Novel and nuisance phytoplankton blooms in the sea: evidence for a global epidemic. In: E. Graneli, B. Sundström, L. Edler and D. M. Anderson (eds.), Toxic Marine Phytoplankton, p 29-40. Elsevier, New York.

Smayda, T.J. and C.S. Reynolds. - 2001. Community assembly in marine phytoplankton: application of recent models to harmful dinoflagellate blooms. J. Plankton Res., 23(5): 447-461.

Solic, M., N. Krstulovic, I. Marasovic, A. Baranovic, T. PucherPetkovic and T. Vucetic. - 1997. Analysis of time series of planktonic communities in the Adriatic Sea: distinguishing between natural and man-induced changes. Oceanol. Acta, 20: 131-143.

Steidinger, K.A. - 1983. A re-evaluation of toxic dinoflagellate biology and ecology. Progr. Phycol. Res., 2: 147-188.

Throndsen, J. - 1995. Estimating cell numbers. In: G. M. Hallegraeff, D. M. Anderson and A. D. Cembella (eds), Manual on harmful marine microalgae, pp. 63-80. IOC Manuals and Guides $\mathrm{N}^{\circ} 33$. UNESCO, Paris.

Tomas, C.R. - 1997. Identifying marine phytoplankton. Academic Press, St. Diego.

Varela M., R. Prego, M. Belzunce, F. Martín-Salas. - 2001. Inshore-offshore differences in seasonal variations of phytoplankton assemblages: the case of a Galician Ria Alta (Ria de A Coruña) and its adjacent shelf (NW of Spain). Cont. Shelf Res., 21: 1815-1838.

Velikova, V., S. Moncheva. and D. Petrova. - 1999. Phytoplankton dynamics and red tides (1987-1997) in the Bulgarian Black Sea. Water Sci. Technol., 39: 27-36.

Vila, M. - 2001. Harmful Algal Blooms in the Catalan coast (NW Mediterranean). PhD thesis. Universitat de Barcelona.

Vila, M, J. Camp, E. Garcés, M. Masó and M. Delgado. - 2001a. High resolution spatio-temporal detection of potentially harmful dinoflagellates in confined waters of the NW Mediterranean. J. Plankton Res., 23(5): 497-514.

Vila, M, M. Delgado and J. Camp. - 2001b. First detection of widespread toxic events caused by Alexandrium catenella in the Mediterranean Sea. In: G. Hallegraeff, S. Blackburn, C. Bolch and R. Lewis (eds.) Harmful Algal Blooms 2000, pp. 8-11. Intergovernmental Oceanographic Commission of UNESCO, Paris.

Vila, M, E. Garcés, M. Masó and J. Camp. - 2001c. Is the distribution of the toxic dinoflagellate Alexandrium catenella expanding along the NW Mediterranean coast? Mar. Ecol. Prog. Ser., 222: 73-83.

Zingone, A., P. Licandro and D. Sarno. - 2003. Revising paradigms and myths of phytoplankton ecology using biological time series. In: Mediterranean Biological Time Series, CIESM Workshop Monographs, 22: 109-114.

Scient. ed.: D. Vaqué 
